\title{
Modelling the epidemiological trend and behavior of COVID-19 in Italy
}

\author{
Alessandro Rovetta ${ }^{1}$, Akshaya Srikanth Bhagavathula ${ }^{2}$, Lucia Castaldo ${ }^{1}$
}

${ }^{1}$ Mensana srls research and disclosure division, Via Moro Aldo 5 - 25124 Brescia, Italy.

${ }^{2}$ Institute of Public Health, College of Medicine and Health Sciences, UAE University, Al Ain, UAE.

\section{Corresponding author}

Alessandro Rovetta,

Mensana srls research and disclosure division,

Via Moro Aldo 5 - 25124 Brescia, Italy.

Email: rovetta.mresearch@gmail.com

Phone: $+39-3927112808$

ORCID: http://orcid.org/0000-0002-4634-279X 
medRxiv preprint doi: https://doi.org/10.1101/2020.03.19.20038968; this version posted June 7, 2020. The copyright holder for this preprint (which was not certified by peer review) is the author/funder, who has granted medRxiv a license to display the preprint in perpetuity. It is made available under a CC-BY-NC 4.0 International license .

\section{Abstract}

As of May 14, 2020, Italy has been one of the red hotspots for the COVID-19 pandemic. With over 220,000 confirmed cases and almost 33,000 confirmed deaths reported from February, it is necessary to fully understand the spread of COVID-19 in this country. By S.E.I.R. simulation, we estimated the most representative basic reproduction number $\mathrm{R} 0$ for the three most affected regions from February 22 to March 14, 2020. In doing so, we have been able to evaluate the consistency of the first containment measures until the end of April, as well as identify possible SARS-CoV-2 local behavior mutations and specificities. Next to that, through new estimates of the infection mortality rate, we recalculated a more plausible number of real infected. Finally, given the absolutely anomalous trend of the Lombardy region, we looked for correlations between COVID-19 total cases and air pollutants such as PM 10 and PM 2.5.

Keywords: COVID-19, coronavirus, contamination, novel coronavirus, SARS-CoV-2, Europe, Italy. 
medRxiv preprint doi: https://doi.org/10.1101/2020.03.19.20038968; this version posted June 7, 2020. The copyright holder for this preprint

(which was not certified by peer review) is the author/funder, who has granted medRxiv a license to display the preprint in perpetuity.

It is made available under a CC-BY-NC 4.0 International license.

\section{Introduction}

The current surge of COVID-19 pandemic is devastating globally, with over 4,200,000 cases and more than 290,000 deaths reported [3]. In Europe, COVID-19 cases have started to dramatically increase from the first week of March 2020. Of these, Italy was grappling with the worst outbreak, with over 35,713 confirmed cases and around 3000 confirmed deaths by March 18, 2020 [1]. This exponential increase in COVID-19 positive cases in Italy raised turmoil, and the government decree to a lockdown of the entire country [2].

In this research, making use of the epidemic parameters provided by WHO, we utilized the S.E.I.R. mathematical model to predict the trend of infections during the first half of March 2020, when the effects of the lockdown were not yet measurable. This allowed us to signal the presence of SARS-CoV-2 local behavior changes due to possible evolutionary genetic mutations, correlations with pollution like PM 10 and PM 2.5, mismanagement of the crisis by national government agencies, non-compliance with the lockdown rules by citizens or other unknown factors. To do this, it was sufficient to compare the general trend foreseen by the S.E.I.R. with the estimated one as well as highlight the discrepancies between the individual Italian regions.

\section{Methods}

To carry out this study, the most recent data found in the scientific literature relating to COVID19 total and active cases, deaths, recoveries, and all epidemic parameters, have been used [1]. We focused especially on Lombardy since it was by far the most afflicted region in Italy. Considering the novel coronavirus incubation period is around $3-6$ days, with a range from a minimum of 2 days to a maximum of 14 , we firstly examined the population of COVID-19 cases 
medRxiv preprint doi: https://doi.org/10.1101/2020.03.19.20038968; this version posted June 7, 2020. The copyright holder for this preprint (which was not certified by peer review) is the author/funder, who has granted medRxiv a license to display the preprint in perpetuity. It is made available under a CC-BY-NC 4.0 International license.

reported between February $22^{\text {th }}$ and March $14^{\text {th }}, 2020$ [4]. Following this, we analyzed the Pearson linear correlation between the number of COVID-19 total cases and the concentrations of PM 10 and PM 2.5. All daily PM data were collected from the ARPA regional websites in the interval January $1^{\text {st }}-$ May $14^{\text {th }}$. Several monitoring stations were used and all results were provided with a Gaussian $95 \%$ confidence interval. All data have been organized into two time periods such as the "pre-lockdown", from January 1st until February 29th, and the "postlockdown", from March 1st until May $14^{\text {th }}$; this served us to estimate the link between the virus spread and the particulate matter (as emissions dropped dramatically during the lockdown). Other types of correlation with population density and number of inhabitants were also investigated.

\section{S.E.I.R. Modelling}

Assuming true the probable "non-relapse patients" hypothesis, we applied the S.E.I.R. model to predict the novel coronavirus evolution in Italy as it is suitable for describing the spread of a virus in populations where no restrictions have been applied [5]. Thanks to the comparison between the S.E.I.R. values and the theoretical estimates (TE) in the short period, it is likely to highlight essential behavior mutations and/or containment strategies effectiveness. We used S.E.I.R. differential equations and non-linear methods to resolve the gaps analytically [6]. We examined Lombardy, Emilia Romagna, and Piedmont separately because of the huge discrepancy of COVID-19 cases between these and other Italian regions. An iterative algorithm was developed using $\mathrm{C}++$ programming language to find a solution through a finite discretization method [Appendix 2]. Given the very low deaths-population ratio, the total population number has been considered constant. 
medRxiv preprint doi: https://doi.org/10.1101/2020.03.19.20038968; this version posted June 7, 2020. The copyright holder for this preprint (which was not certified by peer review) is the author/funder, who has granted medRxiv a license to display the preprint in perpetuity. It is made available under a CC-BY-NC 4.0 International license.

\section{Software iterative algorithm}

By entering the initial values for the incubation time $1 / \sigma$, the recovery time $1 / \gamma$, the basic reproduction number R0, the number of infected $I_{0}$, and the number of recovered $R_{0}$ on February 22, 2020, the software prints the S.E.I.R. predictions day by day. The best epidemic parameters were estimated through continuous iteration until the "closest values to the real ones" were reached until March 12, 2020. The number of initial incubates was calculated with the formula $\mathrm{E}_{0}=\mathrm{R} 0 \cdot \mathrm{I}_{0}$. We report below the system of equations and their discretization through the finite increment $\delta t$ :

$$
\begin{aligned}
S^{\prime}(t) & =\beta \cdot I \cdot S / N \\
E^{\prime}(t) & =\beta \cdot I \cdot S / N-\sigma \cdot E \\
I^{\prime}(t) & =\sigma \cdot E-\gamma \cdot I \\
R^{\prime}(t) & =\gamma \cdot I \\
N^{\prime}(t) & =0 \\
S_{i+1} & =\beta \cdot I_{i} \cdot S_{i} / N_{i} \cdot \delta t+S_{i} \\
E_{i+1} & =\beta \cdot I_{i} \cdot S_{i} \cdot \delta t+E_{i} \\
I_{i+1} & =\left(\sigma \cdot \mathrm{E}_{i}-\gamma \cdot I_{i}\right) \cdot \delta t+I_{i} \\
R_{i+1} & =\gamma \cdot I_{i} \cdot \delta t+R_{i} \\
N_{i} & =S_{i}+E_{i}+I_{i}+R_{i}
\end{aligned}
$$

. $1 / \gamma$ is the incubation time;

- $1 / \sigma$ is the recovery time;

. $\mathrm{R} 0$ is the basic reproduction number;

- $\quad S$ is the number of susceptible people;

- $E$ is the number of active exposed people (people in incubation);

- $\quad I$ is the number of active infected people;

- $R$ is the number of recovered people (no longer infectable). 
medRxiv preprint doi: https://doi.org/10.1101/2020.03.19.20038968; this version posted June 7, 2020. The copyright holder for this preprint (which was not certified by peer review) is the author/funder, who has granted medRxiv a license to display the preprint in perpetuity. It is made available under a CC-BY-NC 4.0 International license .

\section{R0 statistical analysis}

The compatibility between S.E.I.R. predictions $x_{i}$ and TE values $X_{i}$ was investigated within a closed ball of radius 5 days centered in March 7 (from March 2 to March 12, 2020). We searched for the best infection mortality rate $m$ and basic reproduction number R0 through the minimization of two estimators: the first, called $\Delta$, was the algebraic mean value of the absolute percentage differences $\delta_{i}$ between the best value $X_{i}$ for the $x_{i}$ S.E.I.R. value Gaussian distribution $G\left(X_{i}, \sigma_{i}\right)$ and the $x_{i}$ value itself, according to the formula $\delta_{i}=\left|X_{i}-x_{i}\right| / x_{i}$. This allows us to assess the quality of the S.E.I.R. modeling. The second, called $\varepsilon$, was the algebraic mean value of the ratios $\beta_{i}$ between the fixed standard deviation $\sigma_{i}=\left[1 /(n-1) \cdot \Sigma_{i}^{n}\left(X_{i}-x_{i}\right)^{2}\right]$ and the corresponding $x_{i}$, according to the formula $\beta_{i}=\sigma_{i} / x_{i}$. This allow us to calculate the $x_{i}$ relative errors. The lower the $\Delta$, the more representative R0 is of the TE evolution; the lower the $\varepsilon$, the more accurate is the TE. The iteration was carried out until $\varepsilon$ and $\Delta$ minimums were reached. The finite increments chosen for $m$ and $\mathrm{R} 0$ were $\delta m=0.2$ and $\delta \mathrm{R} 0=0.1$ respectively. Every combination with $m$ in $[0.7,1.5]$ and $\mathrm{R} 0$ in $[1,7]$ was tried. The chosen significance limit for $\varepsilon$ and $\Delta$ was 0.1 (i.e. $\Delta$ and $\varepsilon$ must be lower than or equal 0.1 for a result to be acceptable); the iteration ended when $\Delta$ and $\varepsilon<0.05$. The best $\mathrm{R} 0$ confidence intervals were calculated considering the Gaussian distribution $G(\mathrm{R} 0,2 \cdot \delta \mathrm{R} 0)$. We reported a range interval "CRI" for all compatibles R0 we found. All the analysis was carried out through our $\mathrm{C}++$ software and Microsoft Excel. Since $m$ is subject to a very wide margin of error, when more than one $(m, \mathrm{R} 0)$ compatible couple was computed, we utilized the weighted average $m_{\text {best }}=\left(\sum_{i}^{n} m_{i} w_{i}\right) /\left(\Sigma_{i}^{n} w_{i}\right)$, with $w_{i}=\sigma_{i}{ }^{-2}$.

\section{COVID-19 real cases estimate}


medRxiv preprint doi: https://doi.org/10.1101/2020.03.19.20038968; this version posted June 7, 2020. The copyright holder for this preprint (which was not certified by peer review) is the author/funder, who has granted medRxiv a license to display the preprint in perpetuity. It is made available under a CC-BY-NC 4.0 International license .

In order to calculate the real number of COVID-19 total cases in Lombardy, we used an estimation method we called "Theoretical Estimate" (TE). Thanks to the results of another study, in which the number of regional and national deaths until May 5, 2020, was compared with those of the previous 5 years, it was possible to calculate the number of theoretical cases by adding the number of COVID-19 missing cases until the expected infection mortality was achieved [7]. To do this, we considered a mortality rate free to vary in the range $[0.6,1.6][7-9]$. The "COVID19 total deaths number" was shifted 7 days backward due to the time between contracting the disease and demise. We also calculated the difference between confirmed and estimated COVID19 trough the ratio $\alpha=$ estimated cases / confirmed cases.

\section{PM 10 data analysis}

First, we collected PM 10 daily averages data on the most affected cities of the three main regions involved in the COVID-19 epidemic, such as Lombardy, Piedmont and Emilia Romagna; then, we did the same for some regions where the novel coronavirus spree was not so pressing, like Lazio and Campania. Finally, we built the symmetric correlation matrix $\rho_{i j}$

\begin{tabular}{|l|l|l|l|}
\hline 1 & & & \\
\hline$\rho_{12}$ & 1 & & \\
\hline$\rho_{13}$ & $\rho_{23}$ & 1 & \\
\hline$\rho_{14}$ & $\rho_{24}$ & $\rho_{34}$ & 1 \\
\hline
\end{tabular}

where

i. $\quad \rho_{12}$ is the PM $10-$ COVID-19 confirmed cases Pearson correlation index

ii. $\quad \rho_{13}$ is the PM 10 - population density Pearson correlation index

iii. $\rho_{14}$ is the PM 10 - total population Pearson correlation index

iv. $\rho_{23}$ is the COVID-19 cases - population density Pearson correlation index 
medRxiv preprint doi: https://doi.org/10.1101/2020.03.19.20038968; this version posted June 7, 2020. The copyright holder for this preprint (which was not certified by peer review) is the author/funder, who has granted medRxiv a license to display the preprint in perpetuity. It is made available under a CC-BY-NC 4.0 International license.

v. $\rho_{24}$ is the PM $10-$ COVID-19 Pearson correlation index

vi. $\rho_{34}$ is the population density - total population Pearson correlation index

However, since the first outbreak occurred in northern Italy, it is plausible to think the infection did not have the same contagion power in the southern regions; thus, we recalculated the matrix $\rho$ only for the three most infected regions to check whether there was a local correlation. Finally, in order to make the investigation even more precise and specific, we repeated the operation once again to all Lombardy provinces. All the values $\rho_{i j}$ have been reported with their relative pvalues, according to the form $\rho_{i j}(\mathrm{p}$-value $i j)$. All the PM 10 average daily values were reported with Gaussian $95 \%$ confidence intervals $(A V-2 \cdot \sigma / N N, \mathrm{AV}+2 \cdot \sigma / N N)$.

\section{PM 2.5 data analysis}

Since other studies have been conducted on the PM 2.5 - novel coronavirus correlation at national level, we have focused exclusively on the Lombardy region, analyzing the data of all the monitoring units of all the provinces through the previous defined $\rho$ correlation matrix [10].

\section{Results}

\section{Epidemic forecast}

For each infection mortality rate $m$ a compatible value of R0 was found; therefore, we utilized the weighted average $m=0.011$ (95\% CI: $0.006-0.016)$. For the Lombardy region in the period February 22 - March 12, 2020, using the epidemic parameters $1 / \gamma$ and $1 / \sigma$ provided by WHO, we estimated a basic reproduction number R0 $=3.91(95 \% \mathrm{CI}: 3.87-3.94$, CRI: $3.82-3.91)$, with $\Delta$ $=0.02(95 \%$ CI: $0.01-0.03)$ and $\varepsilon=0.04(95 \%$ CI: $0.03-0.05)$. The estimated number of real infections exceeds that of confirmed infections by a factor $\alpha \sim 34$ until May 1, $2020(\alpha=34.1$, 
medRxiv preprint doi: https://doi.org/10.1101/2020.03.19.20038968; this version posted June 7, 2020. The copyright holder for this preprint (which was not certified by peer review) is the author/funder, who has granted medRxiv a license to display the preprint in perpetuity. It is made available under a CC-BY-NC 4.0 International license .

95\% CI: 33.0 - 35.3). The separation point between S.E.I.R. and TE trends is positioned in a neighborhood of March 12, 2020; ergo, that is the period when the lockdown began to take effect [Figure 1]. The two corner points I and II in figure 1 indicate further decreases in R0. About Emilia Romagna, we estimated a basic reproduction number R0 $=2.22$ (95\% CI: $2.18-2.26$, CRI: $2.20-2.23)$, with $\Delta=0.09(95 \%$ CI: $0.07-0.13)$ and $\varepsilon=0.10(95 \%$ CI: $0.08-0.12)$ in the same Lombardy investigation period. At May 1, 2020, the estimated number of Emilia Romagna real infections exceeds that of confirmed infections by a factor $\alpha \sim 24(\alpha=23.7,95 \%$ CI: 23.3 23.9). The substantial differences between the Lombardy and Emilia Romagna R0s show the behavior of SARS-CoV-2 is local i.e. it is potentially linked to demography, air quality, genetic mutations and other factors. Furthermore, in Emilia Romagna the novel coronavirus seemed to have circulated longer naturally (as if the lockdown was not in progress) however causing less serious damage than in Lombardy. In particular, the corner point I in figure 2 signals an R0 increase which lasted approximately until March $21^{\text {st }}$ [Figure 2]. As for Piedmont, we estimated a R0 $=2.52$ (95\% CI: $2.48-2.56)$, with $\Delta=0.07$ (95\% CI: $0.01-0.13)$ and $\varepsilon=0.07$ (95\% CI: 0.06 - 0.09) from February 29 to March 14, 2020. In fact, Ministry of Health data show the infection appears to have started about a week late in this region. Moreover, an important slope increase has occurred at March 14 (15 $5^{\text {th }}$ day) [Figure 3]; this remained almost constant until April 4 (corner point II). On April 25, the estimated COVID-19 total cases in Piedmont exceed those confirmed by a factor $\alpha=23(\alpha=22.5,95 \%$ CI: 22.0 - 23.0). Between March 23 - 24, we begin to notice the first real positive effects of the lockdown.

\section{Pollution correlation}

No significant correlation between SARS-CoV-2 and PM 10 was found. In particular, neither at national nor local level, a p-value $<.1$ has been reached and the higher Pearson index achieved 
medRxiv preprint doi: https://doi.org/10.1101/2020.03.19.20038968; this version posted June 7, 2020. The copyright holder for this preprint (which was not certified by peer review) is the author/funder, who has granted medRxiv a license to display the preprint in perpetuity. It is made available under a CC-BY-NC 4.0 International license .

was $\rho=.34$ [Tables 1 and 2]. Despite this is not enough to completely rule out any link between the novel coronavirus and this type of pollution, and ulterior investigations must be carried out at the molecular level, this allows us to state that PM 10 certainly cannot be the only discriminant characterizing the SARS-CoV-2 spread and virulence. On the contrary, a moderate correlation between SARS-CoV-2 spread and PM 2.5 was highlighted in Lombardy during the first two weeks of March, with a p-value $=.07$ and a Pearson correlation coefficient $\rho=.56$ [Tables 3 and 4]. Beyond that time, the above correlation has decreased in favor of a stronger SARS-CoV-2 provinces population number correlation $(\mathrm{p}$-value $<.0001, \rho=0.9)$ [Figure 4]. This indicates a very large fraction of the total Lombardy population has been infected by the virus. At the same time, no correlation between PM 2.5 and the other measured quantities was found. As confirmation of the lower virus contagiousness and spread in Emilia Romagna, the SARS-CoV-2 - provinces population number correlation grew much more slowly than in Lombardy, reaching its maximum value on 14 May, $2020(\rho=.57$, p-value $=.11)$. Finally, in Piedmont there was a strong correlation between the COVID-19 cases and the population density $(\rho=0.71$, p-value $=$ 0.048 on May 14, 2020) unlike Emilia Romagna and Lombardy [Appendix 1]. No SARS-CoV-2 - province population number was found ( $\mathrm{p}$-value $>>0.1$ ).

\section{Further results}

The matrices shown in table 4 are greatly in agreement with our COVID-19 total and active cases estimates: in fact, the correlation between PM 2.5 and the novel coronavirus spread in Lombardy was significantly moderate in the first two weeks of March; then, it decreased in correspondence with the rising difference between the S.E.I.R. predictions and the TEs. Moreover, the clear increase in the correlation between the number of COVID-19 total cases and the number of inhabitants of the various provinces of Lombardy supports and motivates what is 
medRxiv preprint doi: https://doi.org/10.1101/2020.03.19.20038968; this version posted June 7, 2020. The copyright holder for this preprint (which was not certified by peer review) is the author/funder, who has granted medRxiv a license to display the preprint in perpetuity. It is made available under a CC-BY-NC 4.0 International license.

shown in figure 1 . However, the moderate correlation with PM 2.5 cannot be the only cause for the significant discrepancy of COVID-19 total cases between Lombardy and the other Italian regions: in fact, Emilia Romagna has an average PM2.5 concentration of $30 \mu \mathrm{g} / \mathrm{m}^{3}$ against the $35 \mu \mathrm{g} / \mathrm{m}^{3}$ of Lombardy, while Piedmont even reaches $39 \mu \mathrm{g} / \mathrm{m}^{3}$ [10]. In addition, no significant COVID-19 rising cases - PM 2.5 correlation was found in Piedmont: in fact, the COVID-19 total cases curve reached a steep slope much later than the other two regions and in a period in which the quantity of PM air pollutants was very low. For example, Turin outbreak became important around March 15, despite the PM 2.5 concentrations in the previous 15 days were $<20 \mu \mathrm{g} / \mathrm{m}^{3}$ [17]. Finally, the age groups of Lombardy and Emilia Romagna are demographically comparable i.e. the greater virulence of SARS-CoV-2 in the first cannot be explained through this data [27, 28]. For all these reasons, it is reasonable to assume the following scenarios:

I. SARS-CoV-2 has undergone evolutionary and anti-evolutionary genetic mutations [18 25]. Anyway, there are some research in contrast with this hypothesis [22].

II. lockdown management has been much more effective in some regions than in others;

III. the location of the outbreaks played a large role in the spread of SARS-CoV-2;

IV. Other factors speed up the spread of SARS-CoV-2 [26].

\section{Discussion}

For this analysis, some educated guesses were made:

- given the antibody response identified in COVID-19 patients it seems unlikely the novel coronavirus, without significantly changing, could infect a patient again (in the short term) $[11,12]$ 
medRxiv preprint doi: https://doi.org/10.1101/2020.03.19.20038968; this version posted June 7, 2020. The copyright holder for this preprint (which was not certified by peer review) is the author/funder, who has granted medRxiv a license to display the preprint in perpetuity. It is made available under a CC-BY-NC 4.0 International license .

. $\quad$ the mortality rate is too low to affect the evolution of the S.E.I.R. system [7-9];

. Young people and children appear to have an important role in the spread of infection [13$15]$,

Therefore, to analyze the SARS-CoV-2 dynamics in the initial stages, we have adopted the S.E.I.R. model (Susceptible $\rightarrow$ Exposed $\rightarrow$ Infected $\rightarrow$ Recovered) since it is suitable for describing the spread of a virus in a non-relapse free population. This allowed us to evaluate the effectiveness of the containment measures and/or any virus behavior mutation by comparing S.E.I.R. and theoretical trends [Figures 1 and 2]. Given the absolutely abnormal number of COVID-19 infections and deaths, we treated Lombardy as a stand-alone case; moreover, the modeling we have made concerns exclusively northern Italy since it was the most COVID-19 affected region. Our results show the effectiveness of the Italian lockdown. However, the strong correlation between the total infected and the number of inhabitants in Lombardy suggests the virus nevertheless circulated in a very substantial way among this region i.e. containment measures are likely to have been taken with a heavy delay. In fact, as of May 1, the estimated COVID-19 total cases in Lombardy were almost 3 million. Furthermore, it is plausible the effect of such a latency was aggravated by the presence of PM 2.5 as shown in figure 4 . In this regard, we must point out the COVID-19 cases - PM 2.5 correlation p-value has never exceeded a maximum of .16 and the violation of the significance threshold does not always imply a lack of correlation (and vice versa) [16]. The substantial difference between the basic reproduction number of Lombardy and that of the other two most affected regions is the main symptom of a local behavior of the novel coronavirus. About this aspect, various speculations, hypotheses and theories were made: some of them concern a possible evolutionary genetic mutation of SARS- 
medRxiv preprint doi: https://doi.org/10.1101/2020.03.19.20038968; this version posted June 7, 2020. The copyright holder for this preprint (which was not certified by peer review) is the author/funder, who has granted medRxiv a license to display the preprint in perpetuity. It is made available under a CC-BY-NC 4.0 International license .

CoV-2 in Italy, which has made it more contagious or virulent [18 - 20]; if so, according to what has been pointed out, this should have afflicted Lombardy. Other researches instead assert the virus genetic mutations did not cause mutation in its behavior [22]; if so, the greater Lombard virulence should find explanations in correlation with pollution, delay in the lockdown or other factors, such as a major predisposition of the subjects to be infected and develop sever symptoms $[10,23]$. However, it must be considered that many of these scenarios could prove to be true simultaneously. One hypothesis to be excluded is the bijective relation between local demography and SARS-CoV-2 spread: in fact, Lombardy and Emilia Romagna age groups are totally comparable [27, 28]. The behavior of the novel coronavirus in Piedmont was also peculiar: first of all, despite what happened in Lombardy and Emilia Romagna, we found a strong correlation between the population density and the number of total cases. Furthermore, the epidemic seems to have started with a delay of one week. This fact cannot be explained by the presence of particulate pollution since the concentrations of PM 2.5 and PM 10 were already below the safety threshold due to the quarantine. Therefore, it is possible this episode is linked to virus mutations, people lockdown violations, or other unknown factors. Other dynamics relating to work and university travel must be investigated. As for a possible link between PM 10 and novel coronavirus, we found no significant correlation. At national level, concentrations of PM 10 in some cities of central and southern Italy were comparable to those of Lombardy and Emilia Romagna. In particular, cities like Frosinone, Rome Tiburtina and Naples, where COVID-19 infections were few, had higher values than cities like Brescia and Bergamo where the infection was devastating. Furthermore, PM 10 concentrations in Emilia Romagna and Piedmont are equivalent to Lombard ones unlike the density of COVID-19 cases. Evaluating the hypothesis the first outbreak location was highly incident on the virus spread, we conducted the analysis in 
medRxiv preprint doi: https://doi.org/10.1101/2020.03.19.20038968; this version posted June 7, 2020. The copyright holder for this preprint (which was not certified by peer review) is the author/funder, who has granted medRxiv a license to display the preprint in perpetuity. It is made available under a CC-BY-NC 4.0 International license .

the Lombardy region alone but the result was still negative. The lack of a clear correlation, however, is not sufficient to exclude any relation between PM 10 and SARS-CoV-2 for several reasons:

- unknown factors could alter the data in unpredictable ways and only a molecular investigation will reveal the existence and implications of this phenomenon;

. the town of Codogno, where the first Lombardy outbreak occurred, recorded very high PM 10 average daily values between January $1^{\text {st }}$ and February $29^{\text {th }}\left(67 \mu \mathrm{g} / \mathrm{m}^{3}\right)$ [Appendix $1]$

- the novel coronavirus behavior may not be related to the daily average values of PM 10 but rather to specific thresholds, above which, its virulence and contagiousness would increase considerably. For example, an hour of very intense traffic could favor its spread much more than a constant release of the same particulate matter amount in a longer time lapse.

On the contrary, both at national level (as shown in other studies) and in Lombardy, the correlation with PM 2.5 appeared much more evident and significant. Although it is always necessary to wait for an in-depth molecular study, since there is no correlation between the number of inhabitants and PM 2.5 or between population density and PM 2.5 , the correlation between PM 2.5 and SARS-CoV-2 is very likely causal in nature and far more important than that with PM 10. 


\section{Limitations}

This study is based on the results of other researches, some of which were non peer-reviewed. However, an independent verification of the data provided has been carried out. The S.E.I.R. model predictability is inversely proportional to the prediction temporal distance since the fixed values, such as basic reproduction number, incubation time, and healing time, could change in an unpredictable way; furthermore, iterative methods propagate errors divergently. Anyway, its adoption in the short term remains valid. The mortality rate is considered constant in the period February 22 - May 1, 2020. Regarding PM 10 and PM 2.5 aerosols, we only had access to cities and regions daily average values and the data of some monitoring stations were not available. 
medRxiv preprint doi: https://doi.org/10.1101/2020.03.19.20038968; this version posted June 7, 2020. The copyright holder for this preprint (which was not certified by peer review) is the author/funder, who has granted medRxiv a license to display the preprint in perpetuity. It is made available under a CC-BY-NC 4.0 International license .

\section{Conclusions}

The S.E.I.R. model is approximate as a direct consequence of the uncertainty of the data it was supposed to fit but it can act as a valid comparison for the identification of any SARS-CoV-2 behavior mutations, as well as for the evaluation of the containment measures effectiveness. From the comparison between the S.E.I.R predictions and the estimated real trends highlighted above, as well as between the trends of Lombardy and the other Italian regions, we report that the Italian COVID-19 data are statistically compatible with possible evolutionary mutations of SARS-CoV-2. The demographic similarity between Lombardy and Emilia Romagna, the delayed increase of COVID-19 contagiousness in Piedmont, the absence of an evident statistical correlation with daily PM 10 concentrations and nothing more than a moderate correlation with daily PM 2.5 concentrations, are sufficient reasons to assert the locality of SARS-CoV-2 behavior is also due to factors that are currently unknown. Further investigation is needed. 
medRxiv preprint doi: https://doi.org/10.1101/2020.03.19.20038968; this version posted June 7, 2020. The copyright holder for this preprint (which was not certified by peer review) is the author/funder, who has granted medRxiv a license to display the preprint in perpetuity. It is made available under a CC-BY-NC 4.0 International license .

\section{References}

[1] Italy Civil Protection Department, COVID-19 Italy - Situation Monitoring http://opendatadpc.maps.arcgis.com/apps/opsdashboard/index.html\#/b0c68bce2cce478eaac82fe3 $\underline{8 \mathrm{~d} 4138 \mathrm{~b} 1}$

[2] CNN, All of Italy is in lockdown as coronavirus cases rise, Updated 1850 GMT (0250 HKT) March 13, 2020

https://edition.cnn.com/2020/03/09/europe/coronavirus-italy-lockdown-intl/index.html

[3] WHO Coronavirus disease 2019 (COVID-19), Situation Report 115

https://www.who.int/docs/default-source/coronaviruse/situation-reports/20200514-covid-19sitrep-115.pdf?sfvrsn=3fce8d3c_6

[4] WHO Coronavirus disease 2019 (COVID-19), Situation Report 73

https://www.who.int/docs/default-source/coronaviruse/situation-reports/20200402-sitrep-73covid-19.pdf?sfvrsn=5ae25bc7_6

[5] Swiss TPH, Department of Epidemiology and Public Health Health Systems Research and Dynamical Modelling Unit, Introduction to SEIR Models

http://indico.ictp.it/event/7960/session/3/contribution/19/material/slides/0.pdf

[6] Lucia Castaldo, Alessandro Rovetta, Discretization of differential systems through finite increment iterative algorithms in C++, March 2020, DOI: 10.13140/RG.2.2.29739.39202

https://www.researchgate.net/publication/339851464_Discretization_of_differential_systems_thr ough_finite_increment_iterative_algorithms_in_C

[7] Chirag Modi, Vanessa Bohm, Simone Ferraro, et al. How deadly is COVID-19? A rigorous analysis of excess mortality and age-dependent fatality rates in Italy, medRxiv 2020.04.15.20067074

https://doi.org/10.1101/2020.04.15.20067074 
medRxiv preprint doi: https://doi.org/10.1101/2020.03.19.20038968; this version posted June 7, 2020. The copyright holder for this preprint (which was not certified by peer review) is the author/funder, who has granted medRxiv a license to display the preprint in perpetuity. It is made available under a CC-BY-NC 4.0 International license .

[8] Paradisi, Matteo and Rinaldi, Gianluca, An Empirical Estimate of the Infection Fatality Rate of COVID-19 from the First Italian Outbreak (4/18/2020).

http://dx.doi.org/10.2139/ssrn.3582811

[9] Anthony S. Fauci, M.D., H. Clifford Lane, M.D., and Robert R. Redfield, M.D. March 26, 2020, N Engl J Med 2020; 382:1268-1269, DOI: 10.1056/NEJMe2002387

https://www.nejm.org/doi/full/10.1056/NEJMe2002387

[10] Antonio Frontera, MD, Ph.D, Lorenzo Cianfanelli, MD, Kostantinos Vlachos, MD, Ph.D, Giovanni Landoni, MD, George Cremona, MD, PhD, Severe air pollution links to higher mortality in COVID-19 patients: the "double-hit" hypothesis, May 20, 2020,

https://doi.org/10.1016/j.jinf.2020.05.031

[11] Long, Q., Liu, B., Deng, H. et al. Antibody responses to SARS-CoV-2 in patients with COVID-19. Nat Med (2020).

https://doi.org/10.1038/s41591-020-0897-1

[12] Huang AT, Garcia-Carreras B, Hitchings MD, et al. A systematic review of antibody mediated immunity to coronaviruses: antibody kinetics, correlates of protection, and association of antibody responses with severity of disease, DOI: 10.1101/2020.04.14.20065771

https://europepmc.org/article/ppr/ppr152304

[13] Shekerdemian LS, Mahmood NR, Wolfe KK, et al. Characteristics and Outcomes of Children With Coronavirus Disease 2019 (COVID-19) Infection Admitted to US and Canadian Pediatric Intensive Care Units. JAMA Pediatr. Published online May 11, 2020. doi:10.1001/jamapediatrics.2020.1948

https://jamanetwork.com/journals/jamapediatrics/fullarticle/2766037

[14] Centers for Disease Control and Prevention, Coronavirus Disease 2019 (COVID-19), Communities, Schools \& Workplaces, Schools \& Child Care

https://www.cdc.gov/coronavirus/2019-ncov/community/schoolschildcare/schools.html?fbclid=IwAR3up3RkP92AIY70uOQ0RGtcIDyvlo3VXKLX6xwwvUPp8 s6PM30T0qTGL_M 
medRxiv preprint doi: https://doi.org/10.1101/2020.03.19.20038968; this version posted June 7, 2020. The copyright holder for this preprint (which was not certified by peer review) is the author/funder, who has granted medRxiv a license to display the preprint in perpetuity. It is made available under a CC-BY-NC 4.0 International license .

[15] Centers for Disease Control and Prevention, Severe Outcomes Among Patients with Coronavirus Disease 2019 (COVID-19) — United States, February 12-March 16, 2020, Weekly / March 27, 2020 / 69(12);343-346

https://www.cdc.gov/mmwr/volumes/69/wr/mm6912e2.htm?s_cid=mm6912e2_w

[16] Author links open overlay panelJ. ScottArmstrong, Significance tests harm progress in forecasting, Volume 23, Issue 2, April-June 2007, Pages 321-327

https://doi.org/10.1016/j.ijforecast.2007.03.004

[17] Il Sole 24 Ore, Coronavirus in Italy: updated map and case count.

https://lab24.ilsole24ore.com/coronavirus/en/

[18] Pachetti, M., Marini, B., Benedetti, F. et al. Emerging SARS-CoV-2 mutation hot spots include a novel RNA-dependent-RNA polymerase variant. J Transl Med 18, 179 (2020).

https://doi.org/10.1186/s12967-020-02344-6

[19] Rahila Sardar, Deepshikha Satish, Shweta Birla, Dinesh Gupta, Comparative analyses of SAR-CoV2 genomes from different geographical locations and other coronavirus family genomes reveals unique features potentially consequential to host-virus interaction and pathogenesis, medRxiv 2020.04.03.20047977

https://doi.org/10.1101/2020.04.03.20047977

[20] Lucy van Dorp et al. Emergence of genomic diversity and recurrent mutations in SARSCoV-2, Infection, Genetics and Evolution, Volume 83, September 2020, 104351

https://doi.org/10.1016/j.meegid.2020.104351

[21] Peter Forster, Lucy Forster, Colin Renfrew, and Michael Forster, Phylogenetic network analysis of SARS-CoV-2 genomes, PNAS April 28, 2020117 (17) 9241-9243; first published April 8, 2020

https://doi.org/10.1073/pnas.2004999117 
medRxiv preprint doi: https://doi.org/10.1101/2020.03.19.20038968; this version posted June 7, 2020. The copyright holder for this preprint (which was not certified by peer review) is the author/funder, who has granted medRxiv a license to display the preprint in perpetuity. It is made available under a CC-BY-NC 4.0 International license.

[22] Lucy van Dorp, Damien Richard, Cedric CS et al. No evidence for increased transmissibility from recurrent mutations in SARS-CoV-2

https://doi.org/10.1101/2020.05.21.108506

[23] Hangping Yao, Xiangyun Lu, Qiong Chen et al. Patient-derived mutations impact pathogenicity of SARS-CoV-2, medRxiv 2020.04.14.20060160

https://doi.org/10.1101/2020.04.14.20060160

[24] B Korber, WM Fischer, S Gnanakaran, et al. Spike mutation pipeline reveals the emergence of a more transmissible form of SARS-CoV-2, bioRxiv 2020.04.29.069054

https://doi.org/10.1101/2020.04.29.069054

[25] Xiaolu Tang et al. On the origin and continuing evolution of SARS-CoV-2, National Science Review, nwaa036

https://doi.org/10.1093/nsr/nwaa036

[26] Elisa Benetti et al. ACE2 gene variants may underlie interindividual variability and susceptibility to COVID-19 in the Italian population, medRxiv 2020.04.03.20047977

https://doi.org/10.1101/2020.04.03.20047977

[27] Tuttaitalia.it, Population by age, sex and marital status 2017, Emilia Romagna https://www.tuttitalia.it/emilia-romagna/statistiche/popolazione-eta-sesso-stato-civile2019/?fbclid=IwAR1 YbdfpeDe6WD2q0VfIgckXTYZhORzNpjywoB6kwdB0o0Ue578oY2Oab q0

[28] Tuttaitalia.it, Population by age, sex and marital status 2017, Lombardy https://www.tuttitalia.it/lombardia/statistiche/popolazione-eta-sesso-stato-civile2017/?fbclid=IwAR0adNUcOeVyjM_0d0MpobO2ZYUDt829Erh03vGOwCkMkYIz95LqKtNIJk 


\section{Tables}

\begin{tabular}{|c|c|c|c|c|c|c|c|}
\hline \multirow[b]{2}{*}{ Region } & \multirow[b]{2}{*}{ City } & \multicolumn{2}{|c|}{$\begin{array}{c}\text { pre-lockdown (Jan } \\
1, \text { Feb 29) }\end{array}$} & \multicolumn{2}{|c|}{$\begin{array}{c}\text { lockdown (March } \\
\text { 1, May 14) }\end{array}$} & \multirow{2}{*}{$\begin{array}{c}\text { Population } \\
\text { Density } \\
\left(\mathrm{P} / \mathrm{km}^{2}\right)\end{array}$} & \multirow{2}{*}{$\begin{array}{l}\text { Population } \\
\left(\times 10^{6}\right)\end{array}$} \\
\hline & & $\begin{array}{c}\text { PM10 } \\
\text { AV } \\
\left(\mu \mathrm{g} / \mathrm{m}^{3}\right)\end{array}$ & $\begin{array}{l}\text { 95\% Cl } \\
\text { (SEM) }\end{array}$ & $\begin{array}{c}\text { PM10 } \\
\text { AV } \\
\left(\mu \mathrm{g} / \mathrm{m}^{3}\right)\end{array}$ & $\begin{array}{l}95 \% \mathrm{Cl} \\
\text { (SEM) }\end{array}$ & & \\
\hline \multirow{3}{*}{ Lombardy } & Milan & 56 & $50-62$ & 26 & $23-29$ & 2063 & 3.209 \\
\hline & Brescia & 50 & $46-55$ & 27 & $24-30$ & 264.5 & 1.264 \\
\hline & Bergamo & 43 & $38-47$ & 21 & $19-24$ & 417.9 & 1.108 \\
\hline \multirow{3}{*}{$\begin{array}{l}\text { Emilia } \\
\text { Romagna }\end{array}$} & $\begin{array}{l}\text { Reggio } \\
\text { Emilia }\end{array}$ & 54 & $49-59$ & 26 & $22-29$ & 232.2 & 0.533 \\
\hline & Piacenza & 52 & $47-57$ & 24 & $21-27$ & 111.1 & 0.287 \\
\hline & Bologna & 46 & $40-51$ & 21 & $18-24$ & 2773 & 1.006 \\
\hline \multirow{2}{*}{ Piedmont } & Turin & 59 & $51-67$ & 20 & $18-22$ & 331 & 2.282 \\
\hline & Alessandria & 60 & $54-66$ & 26 & $23-30$ & 118.4 & 0.429 \\
\hline \multirow{3}{*}{ Lazio } & Roma & 40 & $38-41$ & 23 & $22-24$ & 810 & 4.354 \\
\hline & $\begin{array}{c}\text { Roma } \\
\text { Tiburtina }\end{array}$ & 51 & $48-54$ & 21 & $19-22$ & 3600 & 0.17 \\
\hline & Frosinone & 51 & $48-55$ & 22 & $21-23$ & 153.3 & 0.496 \\
\hline Campania & Napoli & 50 & $48-51$ & 27 & $26-27$ & 2617 & 3.117 \\
\hline
\end{tabular}

Table 1. Top Italian "PM 10 polluted and COVID-19" affected cities.

\begin{tabular}{|c|c|c|c|}
\hline \multicolumn{4}{|c|}{ correlation matrix (p-values) } \\
\hline $1(0)$ & & & \\
\hline $.20(.56)$ & $1(0)$ & $1(0)$ & \\
$-.22(.52)$ & $.07(.84)$ & $.46(.15)$ & $1(0)$ \\
\hline$-.30(.37)$ & $.34(.31)$ & (.3) & \\
\hline
\end{tabular}

Table 2. May 14. 2020. Top Italian "PM 10 polluted and COVID-19" affected cities correlation matrix. 


\begin{tabular}{|c|c|c|c|c|c|}
\hline Cities & $\begin{array}{c}\text { PM 2.5 } \\
\left(\boldsymbol{\mu g} / \mathbf{m}^{\mathbf{3}}\right)\end{array}$ & $\begin{array}{c}\mathbf{9 5 \%} \mathbf{C l} \\
(\mathbf{S E M})\end{array}$ & $\begin{array}{c}\text { COVID-19 } \\
\text { cases (May 14) }\end{array}$ & $\begin{array}{c}\text { Population } \\
\text { Density (P/km } \mathbf{~})\end{array}$ & $\begin{array}{c}\text { Total Population } \\
\left(\mathbf{x ~ 1 0 ^ { 6 }}\right)\end{array}$ \\
\hline Milan & 43 & $39-46$ & 22151 & 2063 & 3.209 \\
\hline Brescia & 41 & $39-44$ & 14147 & 292.6 & 1.264 \\
\hline Bergamo & 42 & $39-45$ & 12443 & 264.5 & 1.108 \\
\hline Cremona & 47 & $44-51$ & 6323 & 204.5 & 0.362 \\
\hline Monza B. & 44 & $41-47$ & 5287 & 417.9 & 0.872 \\
\hline Pavia & 45 & $41-49$ & 4979 & 742 & 0.89 \\
\hline Como & 39 & $36-42$ & 3629 & 418.4 & 0.339 \\
\hline Varese & 32 & $30-35$ & 3379 & 2228 & 0.6 \\
\hline Lodi & 39 & $37-41$ & 3351 & 292.6 & 0.182 \\
\hline Mantova & 39 & $37-41$ & 3291 & 3729 & 0.872 \\
\hline Lecco & 24 & $21-26$ & 2645 & 177.3 & 0.415 \\
\hline Sondrio & 21 & $19-22$ & 1367 & 184.7 & 0.548 \\
\hline
\end{tabular}

Table 3. Lombardy cities populations, PM 2.5 daily average values from January 1 to May 14. 2020, and COVID-19 total cases until May 14, 2020.

\begin{tabular}{|c|c|c|c|c|}
\hline Date & & correlation & p-values) & \\
\hline \multirow{4}{*}{ March 4. 2020} & $1(0)$ & & & \\
\hline & $.56(.07)$ & $1(0)$ & & \\
\hline & $-.08(.82)$ & $-.33(.32)$ & $1(0)$ & \\
\hline & $-.32(.34)$ & $.11(.75)$ & $.32(.34)$ & $1(0)$ \\
\hline \multirow{4}{*}{ May 14. 2020} & $1(0)$ & & & \\
\hline & $.46(.13)$ & $1(0)$ & & \\
\hline & $.07(.83)$ & $.09(.78)$ & $1(0)$ & \\
\hline & $.30(.34)$ & $.90(.0001<)$ & $.35(.26)$ & $1(0)$ \\
\hline
\end{tabular}

Table 4. Lombardy cities populations, PM 2.5 daily average values, and COVID-19 total cases: most significant correlation values and days. 


\section{Figures}

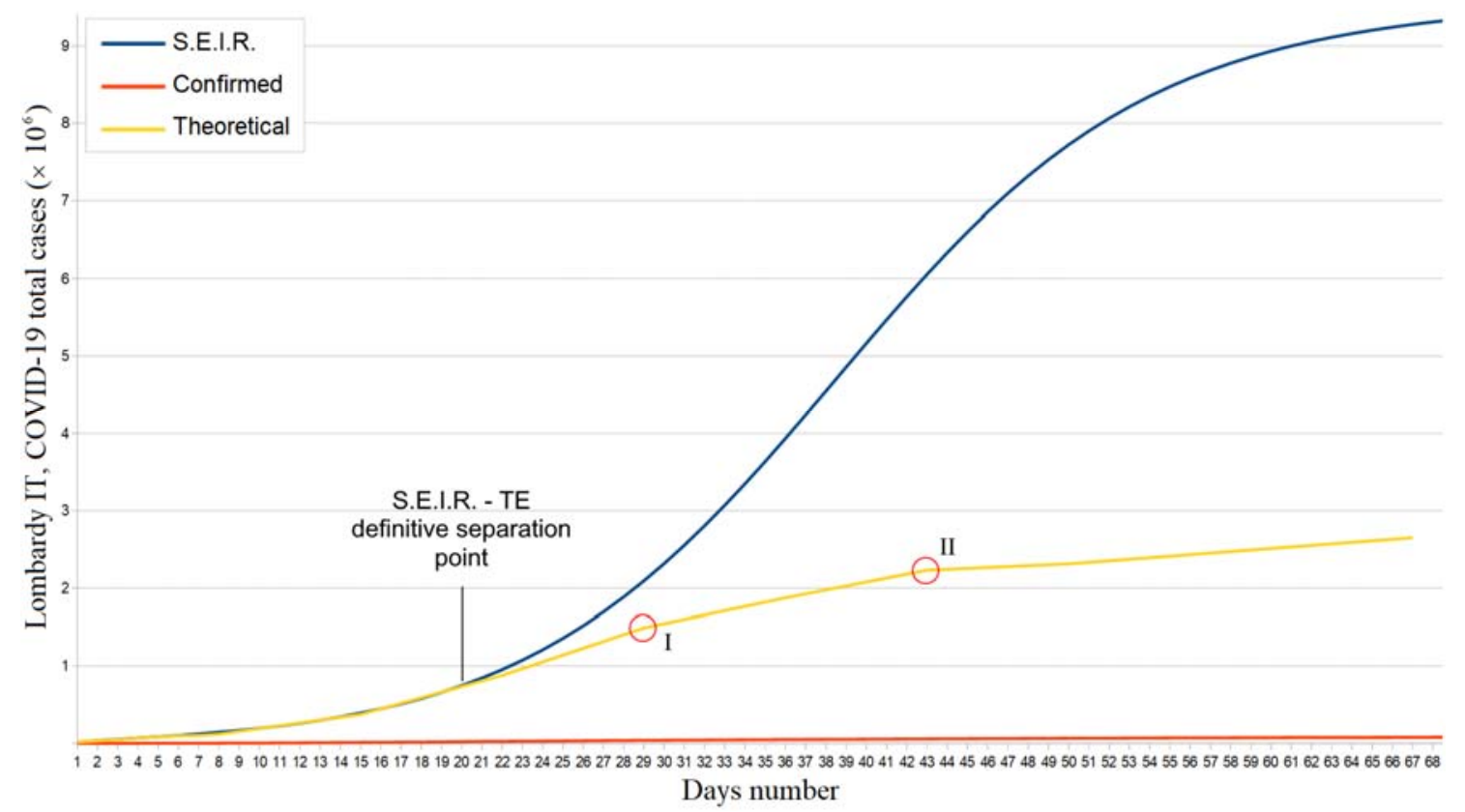

Figure 1. Lombardy confirmed, theoretical, and S.E.I.R. simulation total COVID-19 cases trends from February 22 to May 1, 2020.

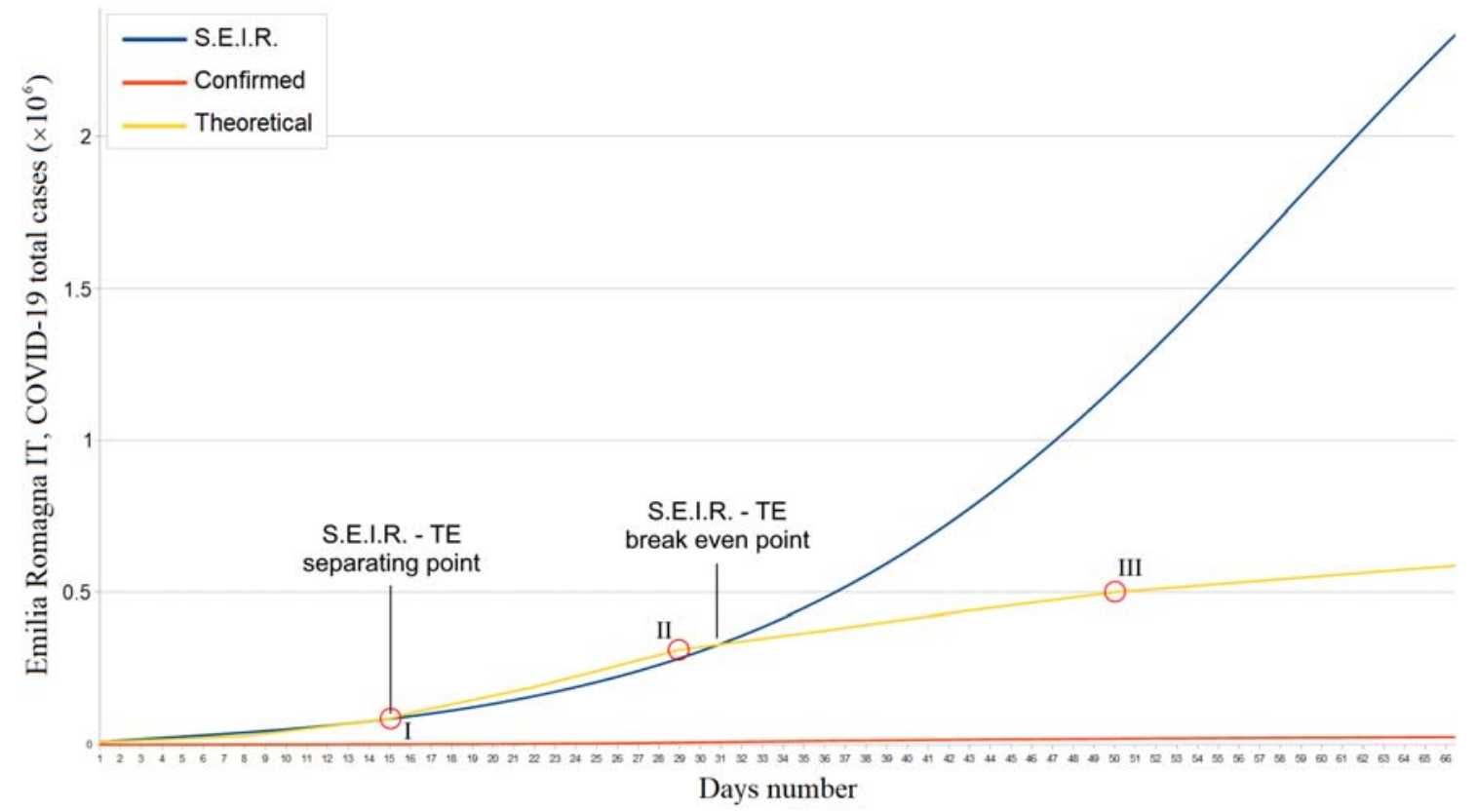

Figure 2. Emilia Romagna confirmed, theoretical, and S.E.I.R. simulation total COVID-19 cases trends from February 29 to April 30, 2020. 
medRxiv preprint doi: https://doi.org/10.1101/2020.03.19.20038968; this version posted June 7, 2020. The copyright holder for this preprint (which was not certified by peer review) is the author/funder, who has granted medRxiv a license to display the preprint in perpetuity.

It is made available under a CC-BY-NC 4.0 International license .

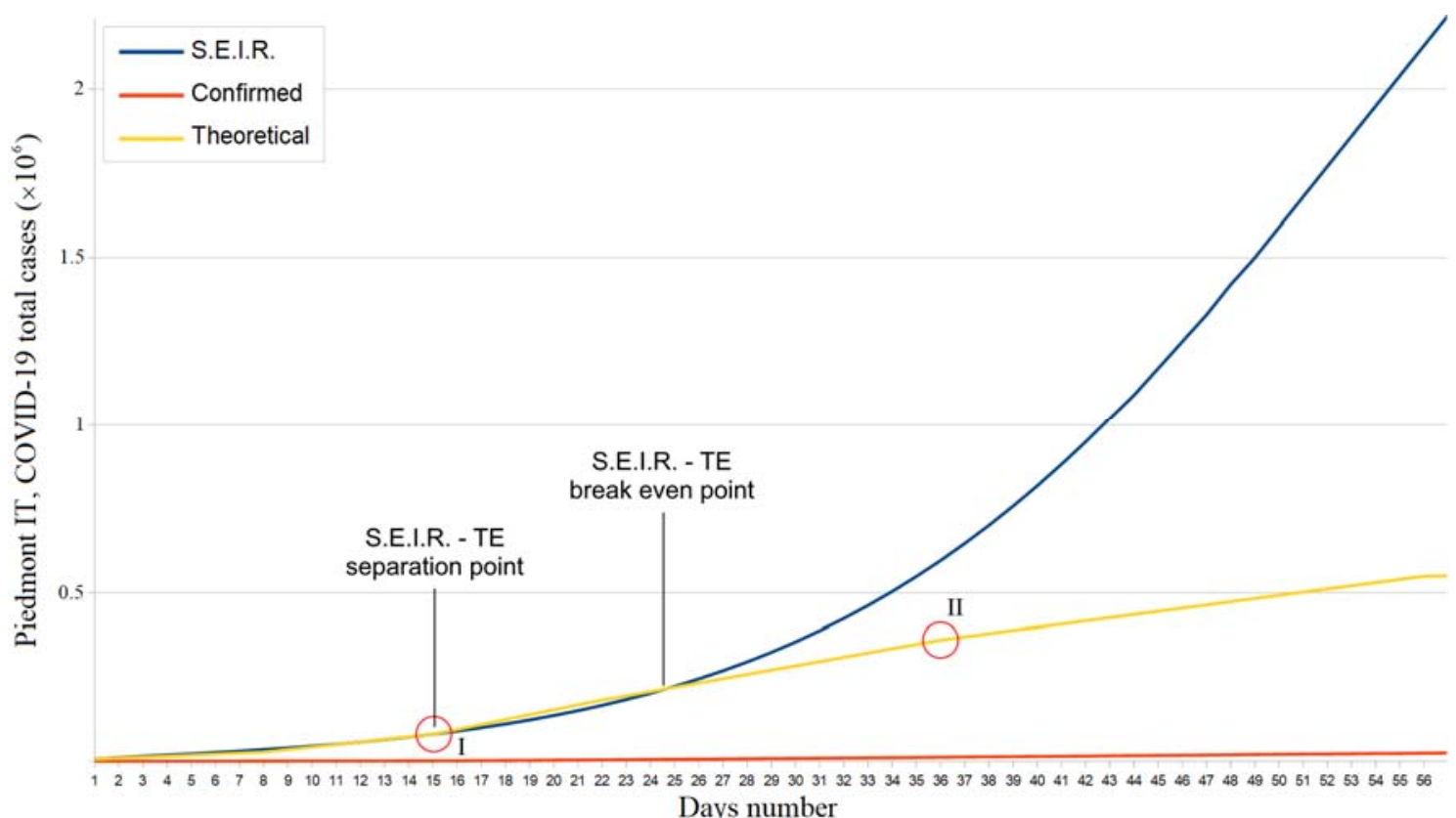

Figure 3. Piedmont confirmed, theoretical, and S.E.I.R. simulation total COVID-19 cases trends from February 29 to April 25, 2020.

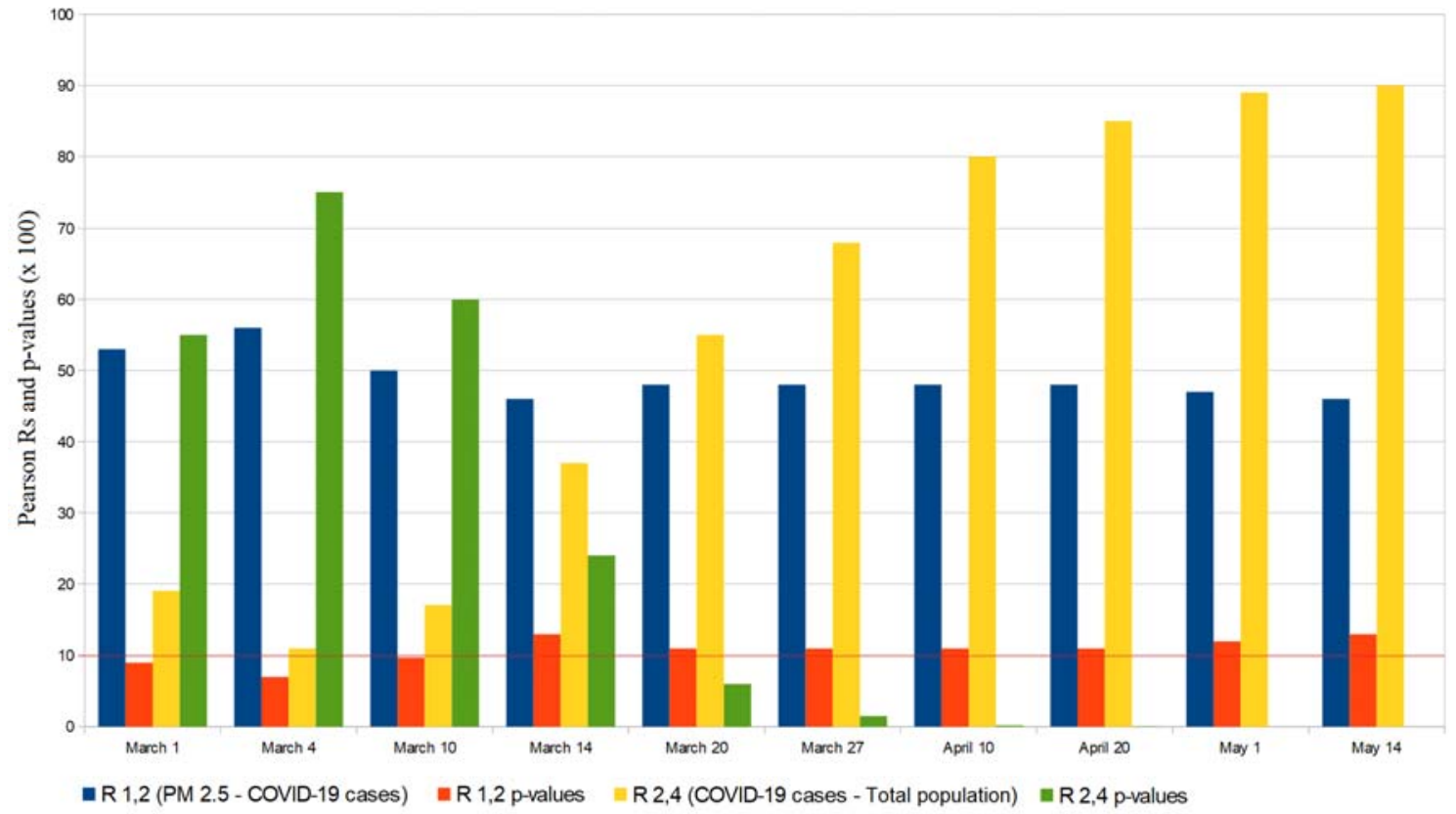

Figure 4. Lombardy cities "PM 2.5 aerosols and populations" correlations with COVID-19 cases. 